\title{
MEASURING AND MODELLING FOREST TRANSPIRATION
}

\author{
Miloslav Šír ${ }^{1}$, Jan Čermák ${ }^{2}$, Nadezhda Nadezhdina², Josef Pražák ${ }^{3}$, Miroslav \\ Tesaŕ ${ }^{1}$ \\ ${ }^{1}$ Institute of Hydrodynamics of the Academy of Sciences of the Czech Republic \\ Praha, Czech Republic \\ ${ }^{2}$ Institute of Forest Botany, Dendrology and Geobiocenology of the Mendel University of Agriculture \\ and Forestry \\ Brno, Czech Republic \\ ${ }^{3}$ Institute of Thermomechanics of the Academy of Sciences of the Czech Republic \\ Praha, Czech Republic \\ milo_sir@yahoo.com, tesarihas@iol.cz,cermak@mendelu.cz,prazak@it.cas.cz
}

\begin{abstract}
The experimental part of the study was performed in the floodplain forest growing along the bank of Dyje River close to Pohansko (about $10 \mathrm{~km}$ east of the town of Breclav, southernmost Moravia). Sap flow was measured by the trunk heat balance (THB) method with direct electric heating of xylem tissues. Two transpiration models were tested, one with plant control, and another without plant control. The principle of the model with plant control is that the physical mechanism of transpiration is evaporation, which is actively controlled by plants. The supposed mechanism is: part of the heat (heat equivalent to the energy absorbed from solar radiation), which would cause heating of the plant above $25^{\circ} \mathrm{C}$, is dissipated by evaporation. The model has five physical parameters, which are in principle measurable independently. The model without plant control is based on the assumption that transpiration dissipates a constant fraction $\mathrm{f}$ of the incoming solar radiation. The later model needs only one parameter which can by found by means of parameter search ( $\mathrm{f}$ is about $45 \%$ in this case). Both models were tested by comparing their results with actual measured transpiration (via sap flow) in the floodplain forest growing along the bank of Dyje River close to Pohansko (Moravia, Czech Republic). The results of the two models were almost identical.
\end{abstract}

Keywords: plant transpiration, SAP flow, floodplain forest.

\section{INTRODUCTION}

The aim of the paper is to evaluate the validity of two transpiration models based on two different approaches. The first of them is described in (Pražák et al. 1994, 1996) and supposes that plants have an ability to control the evaporation in order to optimise their temperature, the second one is based on the assumption that there exists a parameter $f$, fraction of the global radiation above the forest canopy which is used effectively for the evaporation. In this case $f=43,5 \%$. As the third, reference, method a direct measurement of field transpiration similar to potential evapotranspiration was used. This method uses data which can be obtained over most of the growing season in floodplain forests.

Floodplain forests are a very specific ecosystem in the region, usually growing in several hundred-metre-wide belts along rivers, mostly surrounded by arable land where cereals and other agricultural crops are planted. They usually have a non- 
limiting soil water supply (although sometimes soil air supply is limiting, when water remains locally after floods during summer months), and fertile soils that are well supplied by nutrients during regular floods and often by dust blown from surrounding fields. Highly productive broadleaf stands have an upper canopy composed mostly of Quercus, Fraxinus, Tilia, Ulmus, Carpinus, Alnus and Populus, an understorey composed of numerous shrubs (e.g. Cornus, Crataegus, and others) and a rather dense herb layer. Long-term ecosystem-level research has been going on in the region since the late sixties (see comprehensive volumes by Penka et al. 1985, 1991) along with tree and stand-level water relation studies (Penka et al.1979; Čermák et al.1982, 2001; Pietsch et al. 2003; Čermák, Prax 2001).

\section{EXPERIMENTAL SITE}

The experimental part of the study was performed in the floodplain forest growing along the bank of Dyje River close to Pohansko (about $10 \mathrm{~km}$ east of the town of Břeclav, southernmost Moravia). An approximately 2 to $3 \mathrm{~m}$ deep layer of heavy soils of quaternary origin lies on an approximately $8 \mathrm{~m}$ deep layer of sandy gravel of tertiary origin. The experimental stand of sample trees was about 50 to $100 \mathrm{~m}$ from the river bank. The underground water table was within the heavy soil layer on most days of the 1998 growing season, water rose above the soil surface during spring floods about four times a year, and precipitation was lower than potential evapotranspiration from summer until late September. The region is one of the warmest in the Czech Republic.

\section{METHODS}

Daily totals of transpiration were estimated on the basis of sap flow measurements. Sap flow was measured in tree trunks using the trunk tissue heat balance method (THB, Čermák et al. 1973, 2004). Two measuring points (consisting of five electrodes and eight compensating thermocouples, insulated by $2 \mathrm{~cm}$-thick polyurethane foam and $0.5 \mathrm{~mm}$ aluminium tin) were installed at breast height on opposite sides of the trunks. Data were recorded by multi-channel data loggers (EMS Inc., Brno, Czechia) at 15 minute intervals. Altogether 9 sample trees of pedunculate oak (Quercus robur L.) were selected from the closed canopy experimental stand for measurement according to the quintiles of total, so that each tree represented the same fraction of the basal area. Sample trees ranged in diameter at breast height $(\mathrm{DBH})$ from 40 to $80 \mathrm{~cm}$ and heights ranged from 30 to $40 \mathrm{~m}$. The method gave actual data of daily sap flow (seasonal maxims) in the range 0.05 to $0.6 \mathrm{~m}^{3} \mathrm{~d}^{-1}$ for individual trees, which was scaled-up to the stand level on the basis of the sap flow to basal area relationship (see Čermák et al. 2004) with an approximate relative error of about +-10 to $12 \%$.

Two transpiration models were analysed:

Model with plant control (Pražák et al. 1994, 1996): calculates evapotranspiration (ET) as the amount of water needed to protect plants against heating above $25^{\circ} \mathrm{C}$ (overheating). It is supposed that plants are heated by $75 \%$ of global solar radiation (albedo of the plants is estimated to be 25\%). They are also heated or cooled by the surrounding air, where the flux $q$ of the heat exchange between plant and air is given 
by equation $q=\alpha . \Delta T$, where $\alpha=15 \mathrm{~W} \mathrm{~m}^{-2} \mathrm{~K}^{-1}$ is the coefficient of heat transfer and $\Delta T$ is the plant/air temperature difference.

Model with no plant control: ET was calculated as the amount of water evaporated when actually using a fixed value of $43.5 \%$ of the heat equivalent of global radiation above the forest canopy. In this model, no physical mechanism of transpiration is given. No evaporation control is considered, nor the heating/cooling of plants by the surrounding air or the absorbance/reflection of solar radiation. Parameters of both models are given in Table 1.

Table 1: Parameters of two transpiration models.

\begin{tabular}{|l|c|c|}
\hline Model parameters & With plant control & No plant control \\
\hline Optimum plant temperature & $25^{\circ} \mathrm{C}$ & Not considered \\
\hline Global radiation absorbance & $75 \%$ (heats plant) & $\begin{array}{c}43.5 \% \text { (energy for di- } \\
\text { rect evaporation) }\end{array}$ \\
\hline $\begin{array}{l}\text { Coefficient of heat exchange } \\
\text { between plants and air }\end{array}$ & $15 \mathrm{~W} \mathrm{~K}^{-1} \mathrm{~m}^{-2}$ & Not considered \\
\hline
\end{tabular}

No data characterising diurnal courses of temperature and global radiation were available at the time of the calculations, which is why they were reconstructed from daily data (temperature linearly approximated from readings at 7,14 and $21 \mathrm{~h}$ ). The general form of the diurnal course of global radiation was taken from the meteorological station at Churáňov (Šumava Mts.) on cloudless days. This course was fitted to the daily sum of global radiation measured at Pohansko. Uncertainty of results was estimated from the sensitivity analysis, after the form of the diurnal course was modified.

\section{RESULTS}

Measured and calculated transpiration data are shown in Figures 1, 2 and 3 as daily data and cumulative seasonal data. Seasonal totals are given in Table 2. The uncertainty for calculated transpiration daily totals was about $10 \%$. Values of model parameters given in Table 1 are physically sound, lie within the usual range and correspond to data from independent measurements.

Table 2: Seasonal totals (May 1. to Sept.30. 1998) obtained from two transpiration models.

\begin{tabular}{|l|c|c|}
\hline & $\mathrm{kWh} \mathrm{m}^{-2}$ & $\%$ \\
\hline Global radiation income & 720 & 100 \\
\hline $\begin{array}{l}\text { Amount applied for transpi- } \\
\text { ration (= latent heat) }\end{array}$ & 320 & 45 \\
\hline $\begin{array}{l}\text { Amount heating plants and } \\
\text { air (=sensible heat) }\end{array}$ & 400 & 55 \\
\hline Transpiration & $500 \mathrm{~mm}$ & $3.3 \mathrm{~mm} \mathrm{~d}^{-1}$ \\
\hline
\end{tabular}




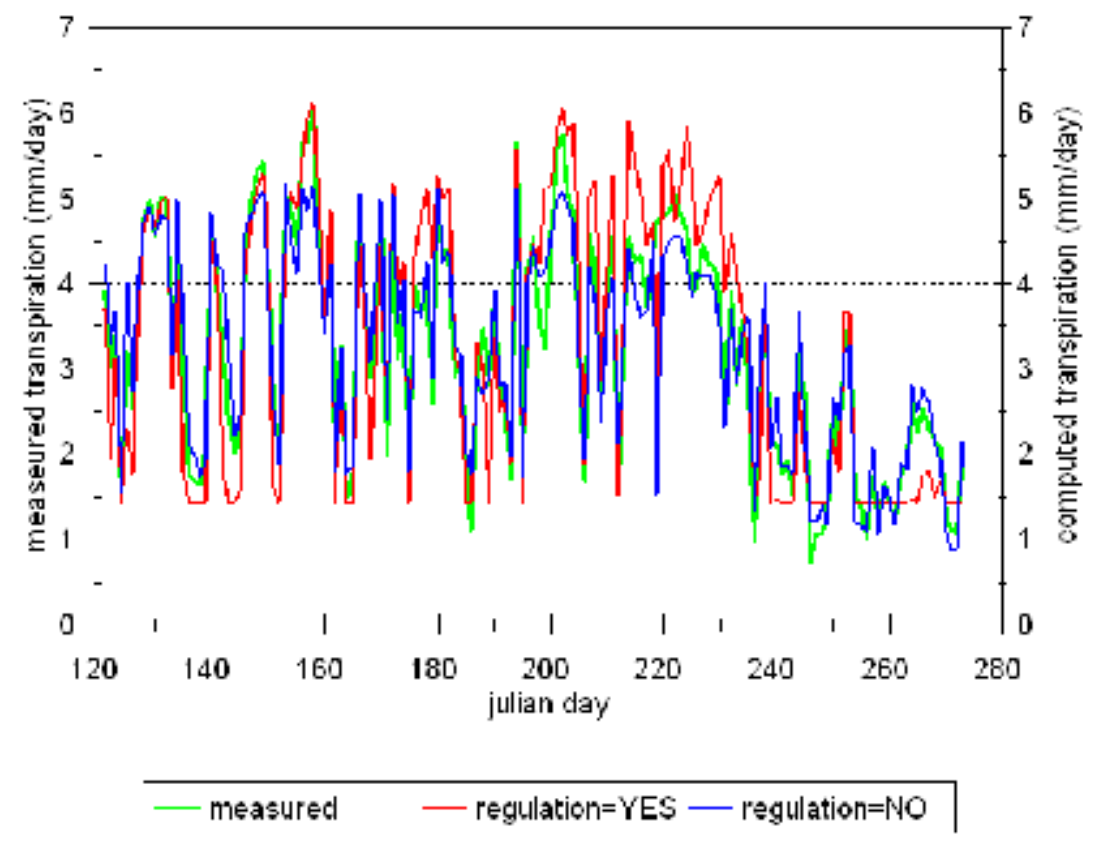

Figure 1: Seasonal course of daily transpiration totals measured directly and those calculated using models a) with plant control, b) without plant control, at the experimental site near Pohansko from May 1 to September 301998.

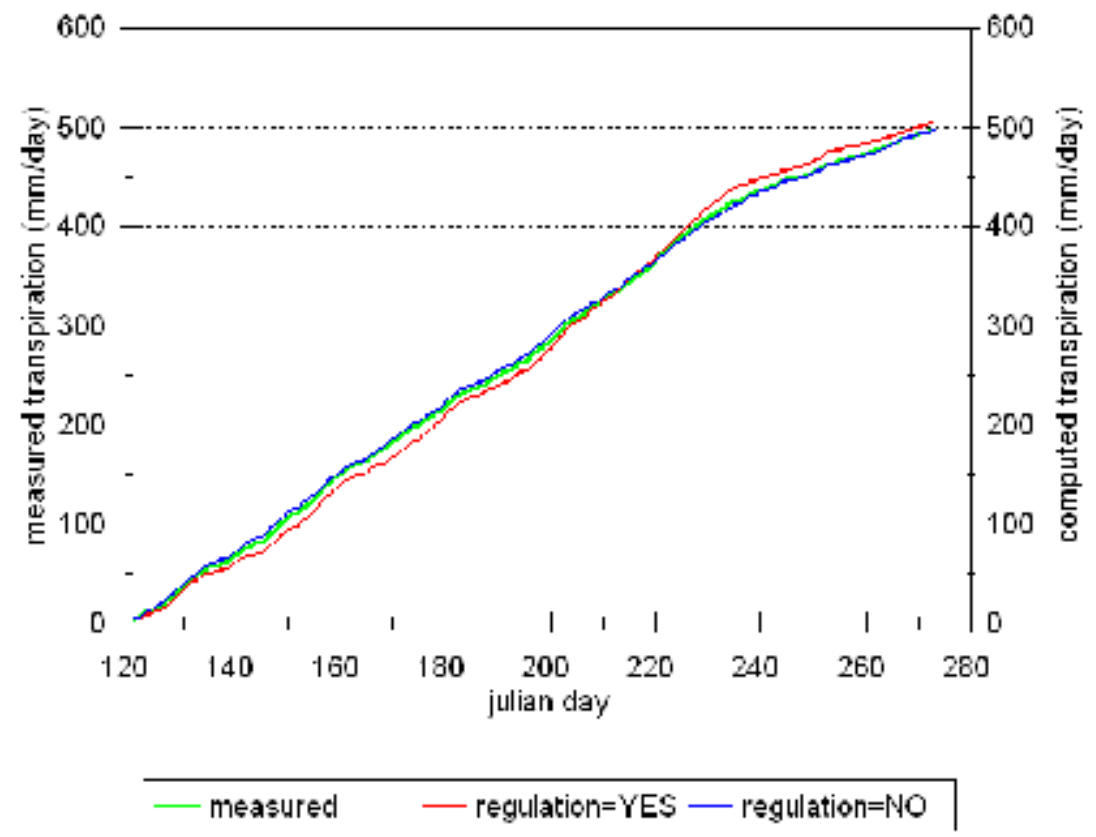

Figure 2: Cumulative seasonal course of daily values of transpiration measured directly and those calculated using models a) with plant control, b) without plant control at the experimental site near Pohansko from May 1 to September 301998. 


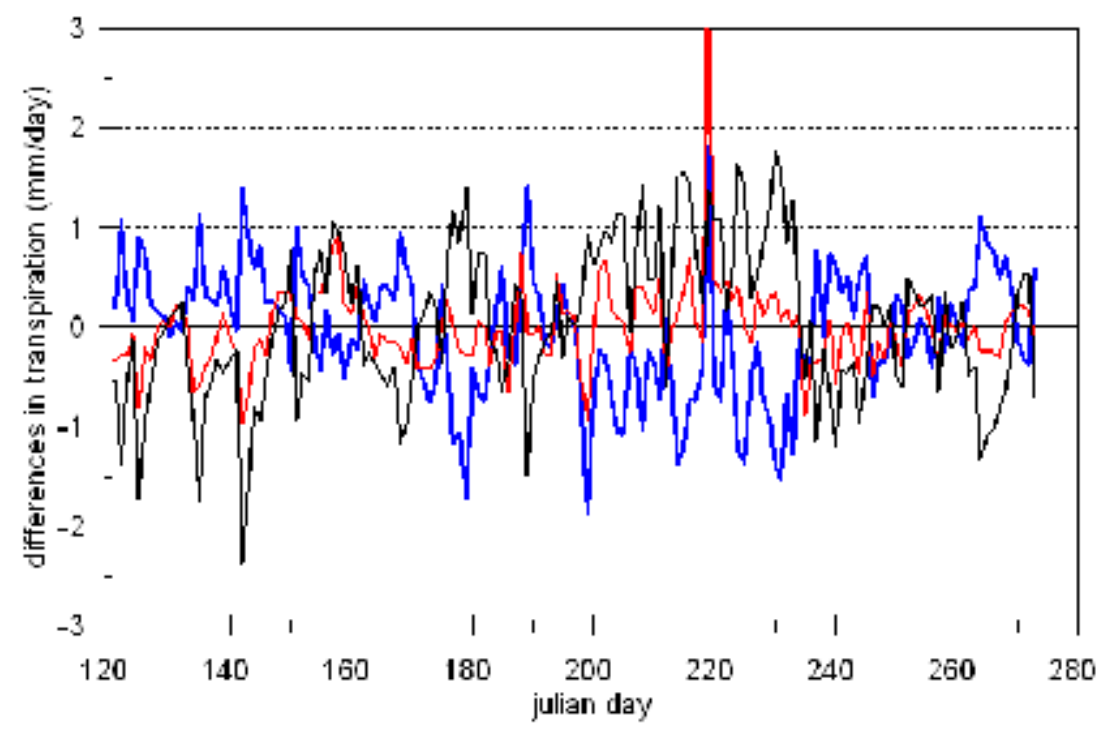

- measured - YES - measured - NO - NO - YES

Figure 3: Differences in daily total transpiration values between measured and calculated data, when using the model with and without plant control.

\section{CONCLUSIONS}

Differences between measured and calculated daily totals were rather small (Figure 2,3 ) and inconsistent (Figure 2, 3). The uncertainty included in the measured and calculated data is much higher than the typical difference of about $1.5 \mathrm{~mm} \mathrm{~d}^{-1}$ between measured and calculated daily transpiration totals (Figure 3 ). We can therefore say that both models are equally valid, based on the similarity of the results.

\section{Acknowledgements}

This research was supported by the Academy of Sciences of the Czech Republic (Institutional Research Plan AV0Z20600510 and Project No. 1QS200420562), Grant Agency of the Czech Republic (Projects No. 205/06/0375, 205/08/1174 and 526/08/1016), Ministry of Education, Youth and Sports (Project No. MEB 0808114) and Ministry of the Environment of the Czech Republic (Project No. SP/1a6/151/07).

\section{References}

Čermák, J., Deml, M., Penka, M. (1973): A new method of sap flow rate determination in trees. Biologia Plantarum (Praha), 15(3); 171-178.

Čermák, J., Úlehla, J., Kučera, J., Penka, M. (1982): Sap flow rate and transpiration dynamics in the full-grown oak (Quercus robur L.) in floodplain forest exposed to seasonal floods as related to potential evapotranspiration and tree dimensions. Biologia Plantarum (Praha) 24(6); 446-460.

Čermák, J., Kučera, J., Prax, A., Bednářová, E., Tatarinov, F., Nadyezhdin, V. (2001): Long-term course of transpiration in a floodplain forest in southern Moravia associated with changes of underground water table. Ekologia (Bratislava) Vol. 20, Suppl. 1; 92-115. 
Čermák, J., Prax, A. (2001): Water balance of the floodplain forests in southern Moravia considering rooted and root-free compartments under contrasting water supply and its ecological consequences. Ann. Sci. For., 58; 1-12.

Čermák, J., Kučera, J., Nadezhdina, N. (2004): Sap flow measurements with some thermodynamic methods, flow integration within trees and scaling up from sample trees to entire forest stands. Trees, Structure and Function, 18; 529-546.

Penka, M., Čermák, J., Štěpánek, V., Palát, M. (1979): Diurnal courses of transpiration rate and transpiration flow rate as determined by the gravimetric and thermometric methods in a full-grown oak tree (Quercus robur L.). Acta Univ. Agric. (Brno), Ser. C, 48(1-4); 3-30.

Penka, M., Vyskot, M., Klimo, E., Vašíček, F. (eds.) (1985): Floodplain Forest Ecosystem: I. Before Water Management Measures. Academia, Praha, $466 \mathrm{pp}$.

Penka, M., Vyskot, M., Klimo, E., Vašíček, F. (eds.) (1991): Floodplain Forest Ecosystem: II. After Water Management Measures. Academia/Elsevier, Praha, 630 pp.

Pietsch, S., Hasenauer, H., Kučera, J., Čermák, J. (2003): Modelling the effects of hydrological changes on the carbon and nitrogen balance of oak in floodplains. Tree Physiology, 23; 735-746.

Pražák, J., Šír, M., Tesař, M. (1994): Estimation of plant transpiration from meteorological data under conditions of sufficient soil moisture. J. Hydrol., 162; 409-427.

Pražák, J., Šír, M., Tesař, M. (1996): Parameters determining plant transpiration under conditions of sufficient soil moisture. J. Hydrol., 183; 425-431. 